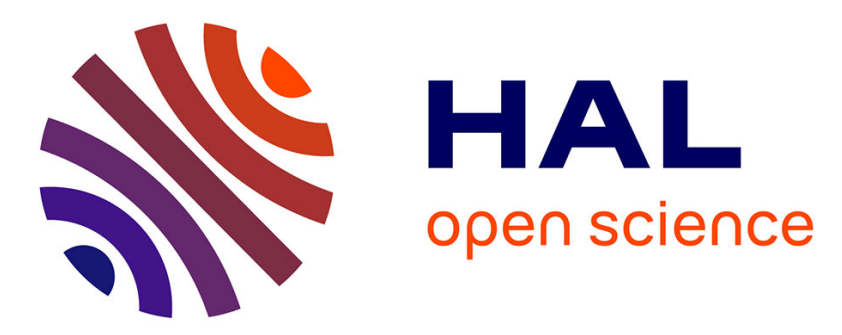

\title{
LCA of EVP - Engineering Veneer Product: plywood glued using a vacuum moulding technology from green veneers
}

Régis Pommier, Guilhem Grimaud, Marion Princaud, Nicolas Perry, Guido Sonnemann

\section{To cite this version:}

Régis Pommier, Guilhem Grimaud, Marion Princaud, Nicolas Perry, Guido Sonnemann. LCA of EVP - Engineering Veneer Product: plywood glued using a vacuum moulding technology from green veneers. Journal of Cleaner Production, 2016, 12 p. 10.1016/j.jclepro.2016.02.130 . hal-01302589

\section{HAL Id: hal-01302589 \\ https://hal.science/hal-01302589}

Submitted on 14 Apr 2016

HAL is a multi-disciplinary open access archive for the deposit and dissemination of scientific research documents, whether they are published or not. The documents may come from teaching and research institutions in France or abroad, or from public or private research centers.
L'archive ouverte pluridisciplinaire HAL, est destinée au dépôt et à la diffusion de documents scientifiques de niveau recherche, publiés ou non, émanant des établissements d'enseignement et de recherche français ou étrangers, des laboratoires publics ou privés. 


\title{
LCA (Life Cycle Assessment) of EVP - engineering veneer product: plywood glued using a vacuum moulding technology from green veneers
}

\author{
Régis Pommier ${ }^{\mathrm{a}, *}$, Guilhem Grimaud ${ }^{\mathrm{a}}$, Marion Prinçaud ${ }^{\mathrm{a}}$, Nicolas Perry ${ }^{\mathrm{b}}$, \\ Guido Sonnemann ${ }^{\mathrm{c}}$ \\ a I2M, UMR 5295, Univ. Bordeaux, Bât. A11, 351 cours de la Libération, 33405 Talence Cedex, France \\ ${ }^{\mathrm{b}}$ Arts et Metiers ParisTech Bordeaux, I2M, UMR 5295, Univ. Bordeaux, Esplanade des Arts et Métiers, 33405 Talence Cedex, France \\ ${ }^{\mathrm{c}}$ Univ. Bordeaux, ISM, UMR 5255, F-33400 Talence, France
}

Keywords:

Plywood production

Life cycle assessment

Vacuum moulding process

Green gluing of wood

\begin{abstract}
A B S T R A C T
The production of plywood represents a major proportion of engineered wood products. The traditional manufacturing process requires very thorough drying of the wood before gluing. Gluing green wood is a new technology which can be applied to plywood vacuum moulding. Gluing wood when it is in a green state can be done, because it can be dried by the vacuum at the same time that pressure is applied for the gluing. The main interest of this method is that it reduces considerably the number of steps in its manufacture. The aim of this paper is to propose a Life Cycle Assessment (LCA) in order to validate the use of the vacuum process with green veneers. The types of glue, the gluing techniques (by vacuum or traditional methods) and the wood varieties have been compared. The functional analysis focused on 4 traditional plywood in order to compare it with our product. The 5 products meet the quality requirements of plywood EN 13986 (2004). The environmental modelling was carried out according to the ISO 14040, standard of life cycle assessment, principles and framework, starting from existing databases and from measurements taken on manufacturing sites and during the testing. The model shows that there is a significant interest in the technology of gluing green wood with a vacuum process compared to the conventional approach. For an industrial use, the disadvantage of this new technology is the use of consumables but that could be reduced considerably in industrial production by using reusable consumables.
\end{abstract}

\section{Introduction}

\subsection{Context of the study}

An efficient and sustainable use of resources requires an integrated assessment of the various aspects related to their exploitation, production, use and end of life, and this can be done with life cycle assessment (LCA) which is considered as an important approach, as it includes parameters for cleaner production. This strategy is more and more widely adopted for innovation and it helps to minimise the impact of new products. Wood based material, being bio-based, needs to be manufactured with respect for the environment. In this way LCA has been used to validate the relevance of a new way of plywood manufacturing. Our study especially focuses on the plywood used in shipbuilding.

\footnotetext{
* Corresponding author.

E-mail address: regis.pommier@u-bordeaux.fr (R. Pommier).
}

Plywood is a material widely employed in the construction of wooden boat hulls. Plywood panels have been sold all over the world for over 100 years and successive innovations have mainly concerned glues and different products for treating the wood (NCASI, 1999). LCAs of plywood were developed in order to discover the environmental impact of the manufacturing of traditional plywood in comparison with other products on the market (Ecoinvent, 2014; Lippke and Wilson, 2010; Wilson, 2010; FIBA and Bureau Veritas, 2011; Bureau Veritas, 2012), but also to identify where the environmental hotspots are in manufacturing (González et al., 2013; González-García et al., 2012a, 2012b, 2013; Ng et al., 2014; Eshun et al., 2012). The LCA of furniture was carried out by Mirabella et al. (2014). It shows that a short supply chain allowed drastic reductions in the impacts compared to long distance transport. In the wood sector, the carbon footprint has recently been the subject of several studies considering the whole industry (Kutnar and Hill, 2014). At the same time, databases have been 
developed in order to quantify effectively the environmental impact of each product on the market. In the boat building industry, the environmental impact of products in contact with the marine environment encourages manufacturers to turn towards materials which are environmentally clean. LCAs have been carried out on bio-based hulls of boats and have shown the environmental interest of these kinds of materials when compared to traditional composites (Réseau EcoNav, 2012; Bertram and Rehdanz, 2013).

Plywood is a material which is difficult to bend for applications to boat hulls. During the second part of the 20th century, its use continued to decline in this sector of activity. By testing its use in the boat building sector, the aim of the proposed study is to determine the environmental advantages and the procedures in the manufacture of plywood by using green gluing of veneers and vacuum moulding techniques. With these two combined techniques it is possible to manufacture bent plywood in compliance with the forms of the boat hulls.

The approach consists in designing a new process for manufacturing plywood according to technical and environmental criteria. The life cycle assessment results will allow us to highlight the hotspots regarding the environment and set the directions for research towards high efficiency sustainable innovation.

\subsubsection{Green gluing of wood}

Interest in green wood gluing grew during the second half of the 20th century. New adhesive formulations were developed to make possible the gluing of wood in a green state (above the fibre saturated point). Wet wood gluing has mainly been studied for glulam and finger jointing processes. This technology has led to improved material yield and increased wood flexibility. Contrary to the traditional gluing processes, wastes or defects (knots, cut offs etc.) are not dried. Only the final product is dried. Studies of green wood gluing have been carried out with different adhesives (Dunky et al., 2008), such as phenol resorcinol formaldehyde (PRF) or melamine urea formaldehyde (MUF). The first results met the requirements for structural use with such adhesives. In France, a one-component polyurethane adhesive was patented in 2002 (Pommier and Elbez, 2006). When applied on wet wood, the polyurethane pre-polymer reacts with the free water and with the water bound to the wood, and this induces a chemical drying of the wood. The mechanical, morphological and chemical properties of this adhesive were detailed by Pommier and Elbez (2006). Other studies were based on the moisture cure polyurethane adhesives (Enquist et al., 2014; Karastergiou et al., 2008; Ren and Frazier, 2012; Serrano et al., 2010). All these research studies have shown positive results for the structural use of green-glued wood. Polyurethanes do not release organic volatile compounds unlike the other structural adhesives.

\subsubsection{Vacuum moulding process}

The vacuum moulding process concerns green plywood manufacturing, associated with the possibility for veneers to be glued but not using either high pressure or high temperature during the green gluing process. It can be pressed between moulds or a vacuum press can be used (Heebink, 1953; Ngo and Pfeiffer, 2003). Examples of bag moulding plywood techniques are illustrated in Fig. 1.

When the vacuum is activated, a differential pressure is created between the inside and the outside of the bagging film that forces the plywood against the mould. Moreover, the glue migrates through the wood cells (Lavalette et al., 2016). Moulded plywood technology was initiated by the boating and aviation industries at the beginning of the 20th century. It has several technical benefits, such as no dimensional limitations, variable thicknesses and shapes allowed in one product and uniform pressure distribution all over the moulded plywood. The equipment required is also low cost and easy to use. These benefits lead us to use this process in this work for shaped hull manufacture. A limitation of this process is that it is hard to get dry veneers to conform to highly curved moulds because they are quite brittle. This drawback could be minimised by using wet veneer. In this study we present the effect of some variables on the panel quality. The panel quality is represented by the ability of the joint to ensure a continuity between two wood pieces, as plywood is an assembly of wood plies. Several parameters play a role in the panel quality and they can be identified as process, adhesive, wood and environmental factors (Clouet et al., 2013; Lavalette et al., 2012; Pommier and Elbez, 2006).

\subsection{Aim and presentation of the ecodesign approach}

The manuscript presents the results of the comparative LCA of 5 different plywoods suitable for shipbuilding. The objective of our study is to highlight the environmental impact of the manufacture of plywood by green gluing process compared to 4 traditional plywoods. So we focus on differences between traditional manufacturing methods that glue dry wood under pressure, and the method where green wood is glued under pressure in a vacuum. The life cycle assessment results will allow us to identify the hotspots regarding the environment impact and set the directions for research into high efficiency sustainable innovation. The fifth solution was modelled with data obtained in laboratory conditions. An optimised fifth solution (5+) was also presented with the help of our first results. We assume that future industrial production will help to reduce the use of consumables used in solution 5 for example. This $5+$ solution was only virtualized on LCA software.

\section{Materials and methods}

\subsection{Field of study}

\subsubsection{Functional unit}

The study was carried out with a comparative environmental LCA according to ISO 14040 and ISO 14044 standards (ISO 14040, 2006; ISO 14044, 2006). The complete LCA appears to be the most robust multicriteria instrument to measure the environmental impact and to make progress in our eco-design approach.

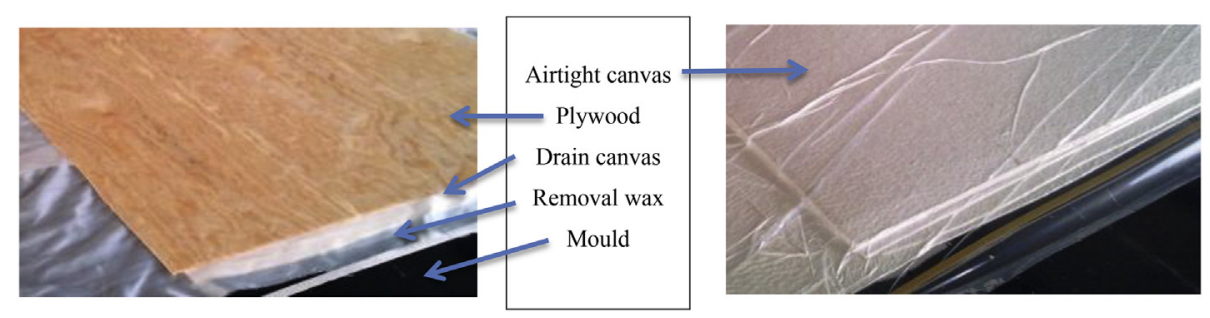

Fig. 1. Example of the covers and materials for vacuum gluing plywood. 
The study remains fairly general as far as the final use of plywood is concerned and it excludes a large number of particularities in boat building in order to concentrate on the plywood manufacturing (Werner, 2004). That is why we wished to widen the functional unit of the study to plywood used for any kind of construction and not just for the plank of a boat hull, which is one of its uses. The functional unit chosen is the following: make $1 \mathbf{~ m}^{2}$ of plywood in a way that it can be used in service class 3 according to EN 313 (1999) and EN 314 (2004) standards for requirements of manufacturing and behaviour of the panels.

\subsubsection{Requirements for compared plywood}

We based our study in Europe. Comparative plywoods are available on the market and manufactured in Western Europe. To validate this technological innovation, our material was tested on a functional prototype "Greencanot", an open motorboat $(8 \mathrm{~m})$ (Pommier et al., 2016). The innovative plywood was made by a shipyard, located in the south west of France. Types of wood and glue were chosen according to the best available technology, based on those most frequently used in shipbuilding firms (except for the prospective solution 5 and $5+$ ). This will allow us to quantify the environmental advantages of using green maritime pine (Pinus pinaster) and this new process to make plywood. The comparative environmental evaluation LCA cradle to grave was selected in order to take into account both the impact of manufacturing as well as the end of the life cycle. In fact, the mechanical properties and the final usage are seen as being similar.

\subsubsection{Presentation of the solutions studied}

We studied the manufacture of plywood panels glued at the wet state under vacuum compared to similar plywood from the market. These panels are intended to form boat hulls, so they should be suitable for exterior use, i.e. EN 314, class 3. Final plywoods were only constructed of five layers of wood and glue to form the $15 \mathrm{~mm}$ thick plywood with only a glue line and without any other treatment. All 5 solutions and a modified fifth solution are shown in Table 1 . Solutions $1-4$, already available commercially, have been selected to serve as a reference for the environmental evaluation of the vacuum process.

Hardwood, Okoume and maritime pine are generally used in marine industries. Phenolic resin and polyurethane are the most commonly used adhesives for structural wood applications.

\subsubsection{Limits of the system}

All the modellings are made from various sources. They had to guarantee the equivalence of the boundaries of each system for an isoperimetric comparison. For this, we have adjusted all the solution boundaries to the same boundaries as Ecoinvent version 2.2. processes. Ecoinvent systems boundaries offer the advantage of being as exhaustive as possible, so this allows us to take environmental impacts into account, as close as possible to reality. In Fig. 2 we have schematised the generic processing steps of each solution.

The cradle to gate methodology is used for the system boundaries, and according to this methodology we exclude life and end of

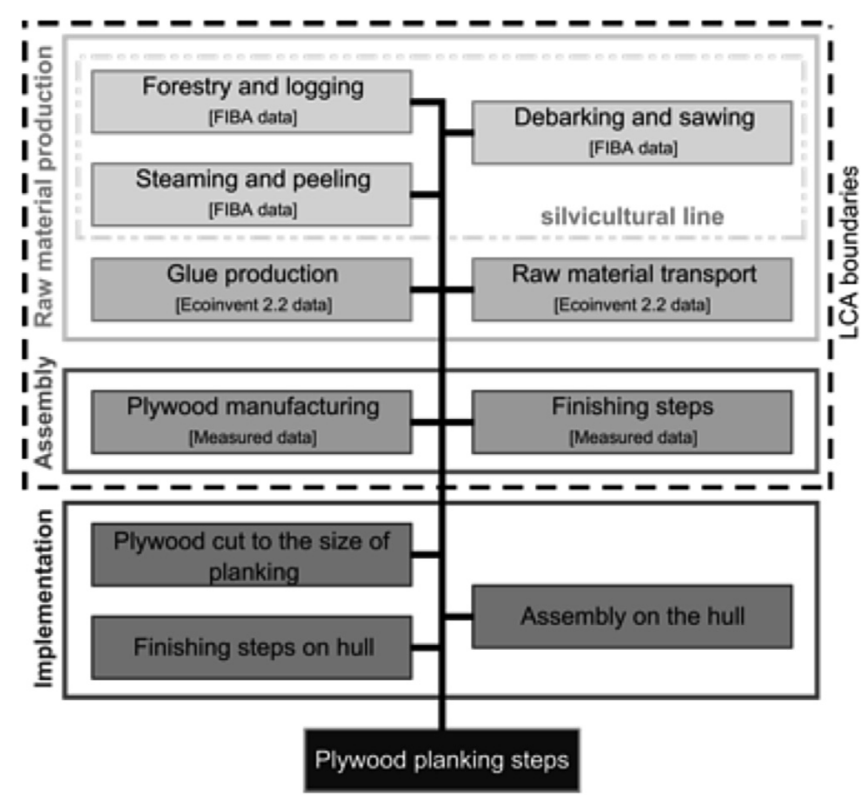

Fig. 2. Green wood planking steps and LCA boundaries.

life steps. This methodology is chosen according to the functional unit in order to focus on the plywood manufacturing.

System boundaries start with tree growth. All the stages in forestry, right up to the maturity of the trees, are integrated into this cycle. Once the tree has been cut down, the process of transforming logs into plywood is analysed and characterised in its entirety. In accordance with the functional unit selected, we set limits on the field of study shown in Fig. 2. Although the research relies on data from the gluing of green wood for a boat, we are not looking at the stages for building the Greencanot (implementation steps).

Moreover, still in accordance with the functional unit, we excluded the life and the end of life steps of the study in order to focus on manufacturing differences.

\subsection{Life cycle inventory}

Data used comes from existing databases first and from measurements taken on manufacturing sites and during the testing. Details are presented in the next paragraphs.

\subsubsection{General points about the manufacture of solutions 1 to 4}

The data collection is referenced in Table 1 . Concerning solutions 1 and 2, existing data from ecoinvent are used. Data LCA performed by FCBA with the methodology of ILCD handbook (European Commission - Joint Research Centre - Institute for Environment and Sustainability, 2010) are used for solutions 3 and 4. The life cycle inventories of these two LCA are based on measurements conducted in France in 2010 and 2011, in accordance with the recommendations of the ILCD handbook.

Table 1

Presentation of the characteristics of 5 solutions studied.

\begin{tabular}{|c|c|c|c|c|c|c|}
\hline Solution & Adhesive type & Wood variety & Gluing & Temperature & Place & Source for modelling \\
\hline 1 & Phenolic resin & Hardwood & Under press & $120^{\circ} \mathrm{C}$ & Europe & BDD Ecoinvent \\
\hline 2 & Polyurethane & Hardwood & Under press & $120^{\circ} \mathrm{C}$ & France & BDD Ecoinvent + modifications \\
\hline 3 & Phenolic resin & Okoume & Under press & $120^{\circ} \mathrm{C}$ & France & From LCA (FCBA, 2012a) \\
\hline 4 & Phenolic resin & Maritime pine & Under press & $120^{\circ} \mathrm{C}$ & France & From LCA (FCBA, 2012b) \\
\hline 5 & Polyurethane & Maritime pine & Vacuum & $20^{\circ} \mathrm{C}$ & France & New modelling Experimental LCI \\
\hline $5+$ & Polyurethane & Maritime pine & Vacuum & $20^{\circ} \mathrm{C}$ & France & New modelling optimised sol. 5 \\
\hline
\end{tabular}


Our comparison is based on the equivalence of the boundaries and the manufacturing stages followed.

Making plywood under pressure takes place in six stages: peeling, sorting, gluing, pressing, sanding and sawing. Logs are first debarked and sawn into widths for the peeling. The next stage is steaming followed by the peeling of the logs. Peeling is necessary to obtain thin veneers of wood, between 0.6 to $4 \mathrm{~mm}$ thick. These layers are first dried then cut up in the right dimensions before they are sorted according to their aspect. The best ones will be used as the face ply, while the others will serve for interior plies that are not visible and are less called upon mechanically.

After this sorting stage the planks are first glued with phenolic or polyurethane glues. For best results, the planks are pressed hot (about $120^{\circ} \mathrm{C}$ ). This operation helps to activate the polymerisation of the glue and bring about a purifying action by destroying living organisms still present in the wood at this stage.

Once the plywood planks are cold and the polymerisation of bond lines are empty, they can go through the finishing stages of sanding and sawing. After cutting into the dimensions required for commercial products, the sanding gives a flat, homogeneous aspect to the surface.

\subsubsection{Procedure for solution 5}

The procedure for solution 5 follows the same steps as the previous solutions leading to peeling. The veneers are then directly used as in Fig. 1 describing the vacuum moulding. The plywood can be made on a flat surface or in the desired shape. Absorbent felt (Fig. 1: non-woven drain canvas) is applied to protect the surface. The felt will be reused several times. A peel ply is used to be easily lifted off the absorbent surface but often this cannot be used more than twice.

Concerning the process, veneers are end glued. The absorbent felt is folded back over the top of the plywood. The airtightness between the vacuum bag and the support is ensured by mastic which surrounds the plywood. One or several vacuum ports are installed above the plywood. Fig. 3 describes the innovative plywood process. It has been done in laboratory conditions. The consumption of glue, other consumables and petroleum products are measured. Data about the wood supply and the peeling process come from the data of solution 4 . The energy of the all the vacuum gluing process is measured.

The optimised $5+$ solution is based on the environmental assessment of the fifth solution with optimisation of some parameters like limitation of waste or optimisation of glue spreading.

\subsubsection{Data source for each solutions}

For each of these material solutions (Table 1) we are using different modelling. Thus in the case of solutions 1 and 2 we used the unitary material sheet available in the Ecoinvent database. We preferred this $\mathrm{dB}$ which provides representative values for a study in Europe and is also one of the best documented databases. The only difference between solutions 1 and 2 lies in the choice of glue. The first one is unchanged, using phenolic resin for the gluing, and the second uses polyurethane glue.

Solutions 3 and 4 were modelled starting from the analyses of the life cycle already carried out on the plywood by the FCBA. Solution 3 concerns the Okoumé plywoods glued under pressure with the phenolic resin. These are plywoods which, up to the present, have been used in boat building for the hulls of wooden boats. Solution 4 models the plywood in maritime pine, still glued under pressure with phenolic resin. This plywood is sold commercially by the firm RolPinSA. These two modellings were carried out as inventories.

The fifth solution presents the modelling of the vacuum moulding technique. This modelling comes from measurements and statements made in the Dubourdieu 1800 SA boatyard during different operations carried out for the building of the Greencanot. This is the functional prototype of an $8 \mathrm{~m}$ open motorboat that was finished in January 2014. All the figures obtained before the building of it came from studies carried out by the FIBA (FIBA and Bureau Veritas, 2011) into forestry exploitation and transformation.

\subsection{Limitations}

In this study we have specified the following variable propositions which are valid for all the solutions examined. Transport is done as directly as possible. The means of transport used are based on reality (loading ratio, type of vehicle, etc.). The place for the transformation of the raw materials is chosen as being the closest to the assembly site. The assembly site is identical to the forest products transformation site; hence no transport is taken into account between the place where peeling takes place and the location of the gluing.

Despite exhaustive research, some elements which are difficult to quantify have been excluded from this study: lighting, heating and the cleaning of the production unit, all small supplies (gloves, masks...), the administrative departments of firms, the transport of employees and clients to the companies. All that elements are excluded from the study because they are not easily quantified

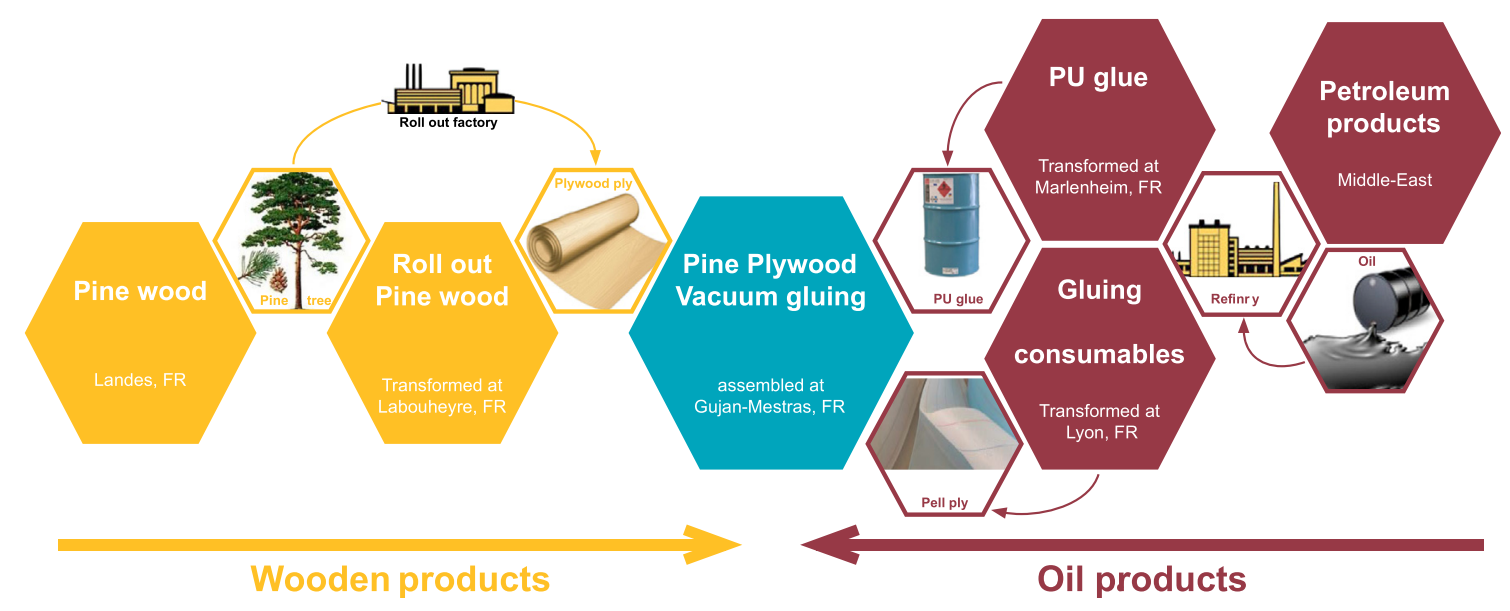

Fig. 3. Flow chart for plywood glued using a vacuum moulding technology from green veneers. 


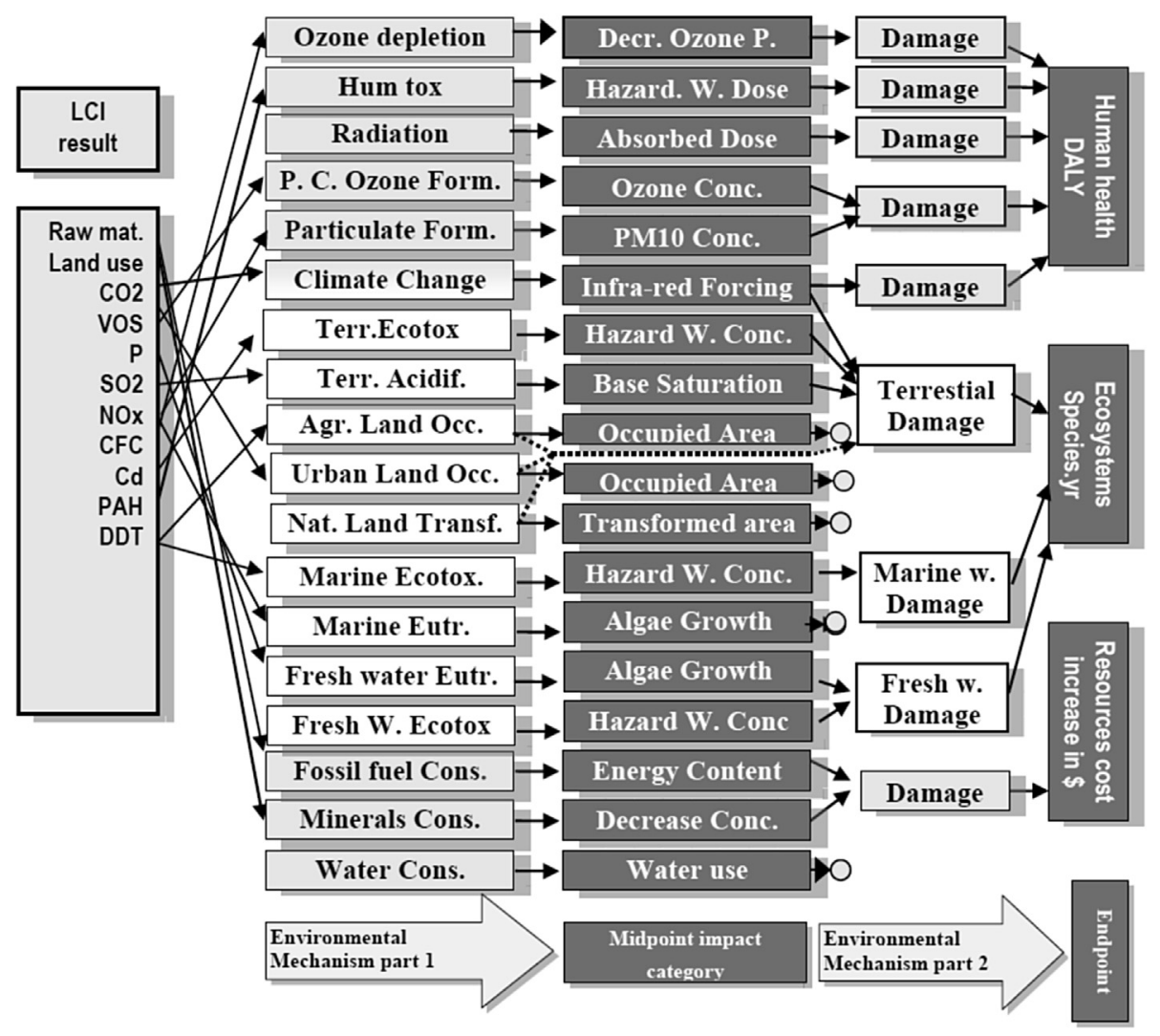

Fig. 4. ReCiPe method relations between LCI parameter, midpoint indicator and end-point indicator.

according to the functional unit. The plant is also used for various productions and a mass allocation will not be relevant as long as the vacuum moulding is not industrialised.

The proportion of non-modelled elements respects the rule whereby less than $2 \%$ of the total mass of the products is unsuitable, and. all the inputs for which the life cycle inventory (LCI) data are available are included in the $\mathrm{LCI}$ of the product. They represent over $99.8 \%$ of the inventory of the study. The proportion of nonconsidered input is inferior by $0.2 \%$ to the whole of the data.

\subsection{Choice of the characterisation model}

\subsubsection{Choice of the calculation method}

The aggregated data is obtained from the calculations of the LCA software. Unless stated to the contrary, the results given in the rest of the report are the result of the ReCiPe Europe MidPoint Hierarchist $(\mathrm{H})$ V1.06 (Ministry of Housing Spatial Planning and the Environment, 2009)calculation method.

In order to give an account of the impacts of each solution and not the consequences determined from the weighting, we chose to use the MidPoint of ReCiPe (Bare et al., 2000) method as well as the USEtox method (Huijbregts et al., 2010) to refine our data on ecotoxicity (Rosenbaum et al., 2008) and human toxicity. Each time, the results were calculated using the European method and not the world one.

For the duration to be taken into account for the calculations made with the help of ReCiPe, we chose to use the hierarchical scale (H). It covers a period of 100-200 years when the egalitarian scale (E) looks at impacts after 500 years by amplifying the indicators for the depletion of resources but does not consider ecotoxicity, and the short term scale (I) examines the infinite resources but definitely increases the ecotoxicity (Curran, 2012).

\subsubsection{Choice of indicators}

The relations between the LCI parameter (left), midpoint indicator (middle) and end-point indicator (right) in the ReCiPe methodology are developed in Fig. 4. Weighting and normalisation are not analysed in this figure.

Table 2presents all the indicators included in our evaluation in comparison with the whole the set of indicators available in the ReCiPe Midpoint methodology. The study included 8 indicators out of 18.

Some methods of calculation allow us to visualise the results for over fifty impact indicators. The reading of these is a delicate exercise even though it's very thorough. The ReCiPe Midpoint method

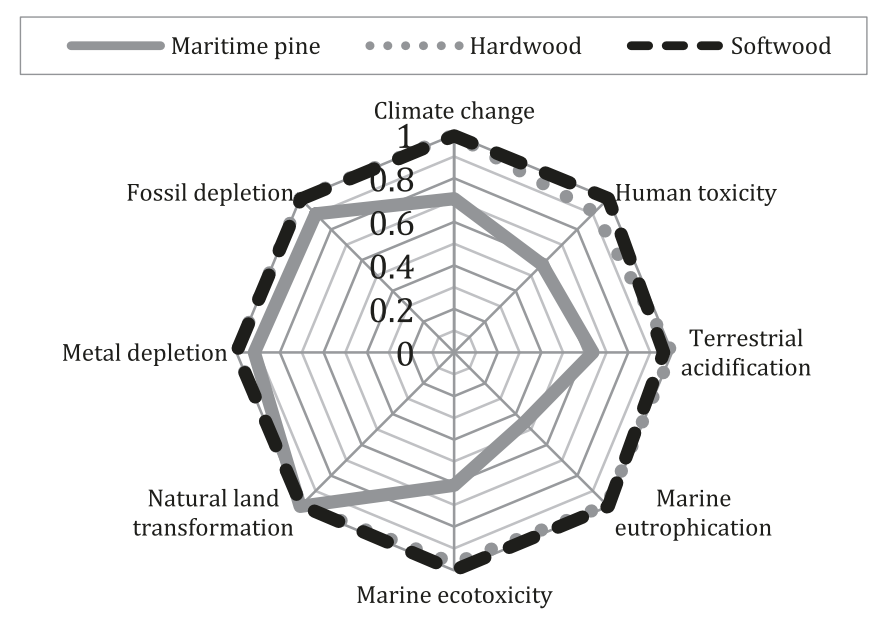

Fig. 5. Characterisation of wood types vacuum glued, ReCiPe Midpoint $(\mathrm{H})$ method. 
Table 2

Set of indicators provided by ReCiPe method and used in our calculation.

\begin{tabular}{lll}
\hline Impact category & Unit & Included in the study \\
\hline Climate change & $\mathrm{kg} \mathrm{CO}$ eq & $\mathrm{X}$ \\
Ozone depletion & $\mathrm{kg} \mathrm{CFC}-11$ eq & \\
Human toxicity & $\mathrm{kg} 1,4-\mathrm{DB}$ eq & $\mathrm{X}$ \\
Photochemical oxidant formation & $\mathrm{kg} \mathrm{NMVOC}$ & \\
Particulate matter formation & $\mathrm{kg} \mathrm{PM} 10 \mathrm{eq}$ & \\
Ionising radiation & $\mathrm{kg} \mathrm{U} 235 \mathrm{eq}$ & \\
Terrestrial acidification & $\mathrm{kg} \mathrm{SO} 2$ eq & $\mathrm{X}$ \\
Freshwater eutrophication & $\mathrm{kg} \mathrm{P} \mathrm{eq}$ & \\
Marine eutrophication & $\mathrm{kg} \mathrm{N}$ eq & $\mathrm{X}$ \\
Terrestrial ecotoxicity & $\mathrm{kg} \mathrm{1,4-DB} \mathrm{eq}$ & \\
Freshwater ecotoxicity & $\mathrm{kg} 1,4-\mathrm{DB}$ eq & \\
Marine ecotoxicity & $\mathrm{kg} \mathrm{1,4-DB} \mathrm{eq}$ & $\mathrm{X}$ \\
Agricultural land occupation & $\mathrm{m}^{2} \mathrm{a}$ & \\
Urban land occupation & $\mathrm{m}^{2} \mathrm{a}$ & \\
Natural land transformation & $\mathrm{m}^{2}$ & $\mathrm{X}$ \\
Water depletion & $\mathrm{m}^{3}$ & $\mathrm{X}$ \\
Metal depletion & $\mathrm{kg} \mathrm{Fe} \mathrm{eq}$ & $\mathrm{X}$ \\
\hline
\end{tabular}

supplies results for 18 environmental impact indicators but they are not all useful for this study.

Sometimes the product has no impact on one or other of them while it may have a major impact on yet another.

In order to help our interpretations, to use the representative data and to make our diagrams clearer, we have selected 8 indicators, which are the most representative of global trends. The choice of indicators was made after studying the results obtained in the form of normalised graphs (Tukker, 2002).

Firstly we chose two emblematic indicators: climate change and human toxicity, which seem to resume easily the global impact of solutions. These two indicators are easy to interpret and give the general trend for the solutions studied. Besides, in order to highlight the most feasible and serious solutions over time, we have included the indicators for the depletion of mineral and fossil resources. These are powerful, emblematic indicators for the comparative LCAs of manufactured products (Curran, 2012).

Finally, we took the context of the study into account, that is to say the marine use of manufactured plywood. We chose to highlight the indicators linked to the marine area: marine eutrophication and marine ecotoxicity, although these are the subject of critical uncertainties (European Commission - Joint Research Centre - Institute for Environment and Sustainability, 2010).

In order to assess the ecodesign approach aiming at promoting the use of local wood, into our set of indicators we integrated two indicators which have a link with the cultivation of wood: the transformation of natural land and, the acidification of the soil.

After reading the normalised graphs we were able to validate or modify the choices of indicators and thus retain a set of indicators which were pertinent and readable within the environmental evaluation framework. We can cite two indicators that, despite their pertinence, only appear in the solutions of the Ecoinvent database on the normalised histograms: toxicity of the land and exhaustion of water resources. We chose to leave these to one side in order to not disadvantage the generic solutions.

\section{Results}

\subsection{First step in our ecodesign approach}

Since the functional unit is limited to plywood, that is to say a material which is made of wood and glue, before our environmental analysis we carried out pre-tests separately on the wooden materials and on the polyurethane and phenolic glues used in our study.

\subsubsection{Comparison of the vacuum process, according to the type of wood}

We compared coniferous and deciduous trees and maritime pine cultivated coniferous trees. Their environmental impacts are supposed to be significantly different. Thus we wanted to know the advantages of vacuum gluing with undetermined types of wood. In order to do this, we integrated generic modelling of hardwood and softwood species to compare with the modelling of maritime pine (solution 5). The results are given in Fig. 4 and Table 2, and show an advantage for maritime pine over softwood or hardwood species.

Fig. 4 shows the results of modelling of generic plywood that is vacuum glued. The impacts of hardwood, softwood and maritime pine are given (Table 3 ).

The comparison shows little difference between these two categories of wood, from averaged models of the Ecoinvent 2.2. $\mathrm{dB}$, so maritime pine proves that its environmental interest is much stronger. We noticed that, besides the proximity of maritime pine resources, the environmental study tends to prove the advantages of changing to maritime pine, which is motivated by factors that are logistical but also environmental. Except for the natural land transformation, the cultivated maritime pine is always advantageous (short rotation, gas capture, soil fertilisation, etc.).

\subsubsection{Comparison of polyurethane glue and phenolic resin}

Over the last few decades phenolic glues have come to dominate the market. The first reason is economic with the polyurethane adhesive about $60 \%$ more expensive per kilogram than phenolic glue. The other advantage is technical as phenolic glue is a low reactivity glue. It therefore has an open time of $4 \mathrm{~h}$ at room temperature, and this time is reduced thanks to heat applied when under pressure.

Nevertheless, polyurethane requires a weight up to $180-250 \mathrm{~g} /$ $\mathrm{m}^{2}$ when phenolic resin needs $250-300 \mathrm{~g} / \mathrm{m}^{2}$. The weight of glue used should be further reduced in the case of green wood where the module of elasticity is below $20 \%$ and the contacts between substrates have been made easier (Pizzi and Mittal, 2011).

Whatever the glue used, the finished product possesses the same mechanical properties and the same finish. Gluing green

Table 3

Characterisation of wood types vacuum glued, ReCiPe Midpoint $(\mathrm{H})$ method.

\begin{tabular}{|c|c|c|c|c|}
\hline Impact category & Unit & Maritime pine & Hardwood & Softwood \\
\hline Climate change & $\mathrm{kg} \mathrm{CO} 2$ eq & $9.002 \mathrm{E}+00$ & $1.274 \mathrm{E}+01$ & $1.268 \mathrm{E}+01$ \\
\hline Human toxicity & kg 1,4-DB eq & $1.187 \mathrm{E}+00$ & $1.895 \mathrm{E}+00$ & $2.078 \mathrm{E}+00$ \\
\hline Terrestrial acidification & $\mathrm{kg} \mathrm{SO}_{2}$ eq & $2.751 \mathrm{E}-02$ & $4.322 \mathrm{E}-02$ & $4.160 \mathrm{E}-02$ \\
\hline Marine eutrophication & $\mathrm{kg} \mathrm{N}$ eq & $3.185 \mathrm{E}-03$ & $6.936 \mathrm{E}-03$ & $7.000 \mathrm{E}-03$ \\
\hline Marine ecotoxicity & $\operatorname{kg} 1,4-\mathrm{DB}$ eq & $2.451 \mathrm{E}-02$ & $3.892 \mathrm{E}-02$ & $4.021 \mathrm{E}-02$ \\
\hline Natural land transformation & $\mathrm{m}^{2}$ & $2.190 \mathrm{E}-04$ & $2.176 \mathrm{E}-04$ & $2.176 \mathrm{E}-04$ \\
\hline Metal depletion & $\mathrm{kg}$ Fe eq & $1.641 \mathrm{E}-01$ & $1.788 \mathrm{E}-01$ & $1.788 \mathrm{E}-01$ \\
\hline Fossil depletion & $\mathrm{kg}$ oil eq & $3.607 \mathrm{E}+00$ & $4.008 \mathrm{E}+00$ & $3.994 \mathrm{E}+00$ \\
\hline
\end{tabular}




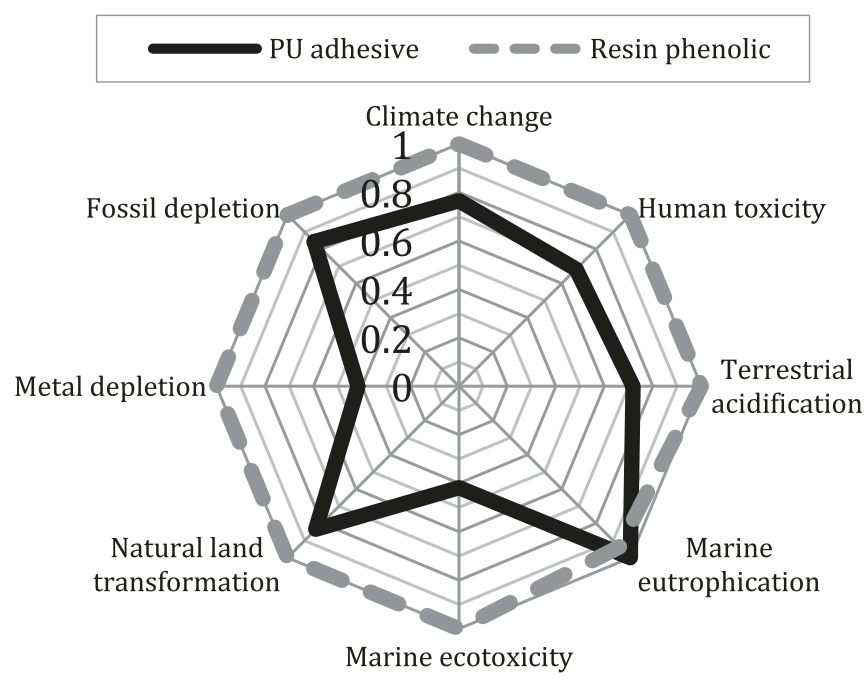

Fig. 6. Characterisation of 2 glues used for gluing plywood ReCiPe Midpoint $(\mathrm{H})$ method.

Table 4

Characterisation of 2 glues used for gluing plywood ReCiPe Midpoint $(\mathrm{H})$ method.

\begin{tabular}{llll}
\hline Impact category & Unit & PU adhesive & Resin phenolic \\
\hline Climate change & $\mathrm{kg} \mathrm{CO}_{2}$ eq & $8.960 \mathrm{E}-01$ & $1.171 \mathrm{E}+00$ \\
Human toxicity & $\mathrm{kg} \mathrm{1,4-DB} \mathrm{eq}$ & $6.696 \mathrm{E}-01$ & $9.799 \mathrm{E}-01$ \\
Terrestrial acidification & $\mathrm{kg} \mathrm{SO} \mathrm{eq}_{2}$ & $3.713 \mathrm{E}+05$ & $1.627 \mathrm{E}+05$ \\
Marine eutrophication & $\mathrm{kg} \mathrm{N} \mathrm{eq}$ & $4.864 \mathrm{E}-03$ & $6.775 \mathrm{E}-03$ \\
Marine ecotoxicity & $\mathrm{kg} 1,4-\mathrm{DB}$ eq $^{2}$ & $4.718 \mathrm{E}-04$ & $4.417 \mathrm{E}-04$ \\
Natural land transformation & $\mathrm{m}^{2}$ & $4.118 \mathrm{E}-03$ & $9.854 \mathrm{E}-03$ \\
Metal depletion & $\mathrm{kg} \mathrm{Fe} \mathrm{eq}$ & $1.218 \mathrm{E}-03$ & $1.459 \mathrm{E}-03$ \\
Fossil depletion & $\mathrm{kg} \mathrm{oil} \mathrm{eq}$ & $3.160 \mathrm{E}-02$ & $7.587 \mathrm{E}-02$ \\
\hline
\end{tabular}

wood requires a polyurethane, which explains the choice of this adhesive for solution 5. Fig. 6 shows the comparison between the two glues used in the manufacturing of plywoods. This figure allows us to validate the environmental interest of polyurethane glue in relation to phenolic glue for the gluing of wood plies in the manufacture of plywoods (Table 4).

Changing from phenolic resin to polyurethane glue for gluing wood plies (solutions 1 and 2 ) allows the reduction of the impact on the whole of the selection of indicators except for marine eutrophication. It could be caused by the release of isocyanates during the manufacture and the polymerisation of the Polyurethane adhesive.

\subsection{Presentation of the results obtained for the comparison of 5 solutions}

\subsubsection{Characterisation results for the comparison of 5 solutions}

Fig. 7 shows the characterised results of the comparison of 5 solutions of plywood with the ReCiPe characterisation method (Table 5).

Generally, the solutions for green gluing of maritime pine veneers using the vacuum process (solutions 4 and 5) have the least impact from an environmental point of view in comparison with traditional gluing solutions. These results prove the interest of using maritime pine in the manufacture of plywood as opposed to deciduous species especially Okoumé. In fact Okoumé and generic plywoods glued with phenolic resin are the two most damaging solutions compared with the other three.

Compared with maritime pine plywood glued under pressure, the vacuum process has a higher impact on one indicator. The depletion of fossil resources indicator is directly linked to the use of consumables (vacuum bag, absorbent felt, etc...) produced by the petrochemical industry for use in the vacuum process, when industrial processes use mechanical or hydraulic press without comparable consummation of consumables. This study enables us

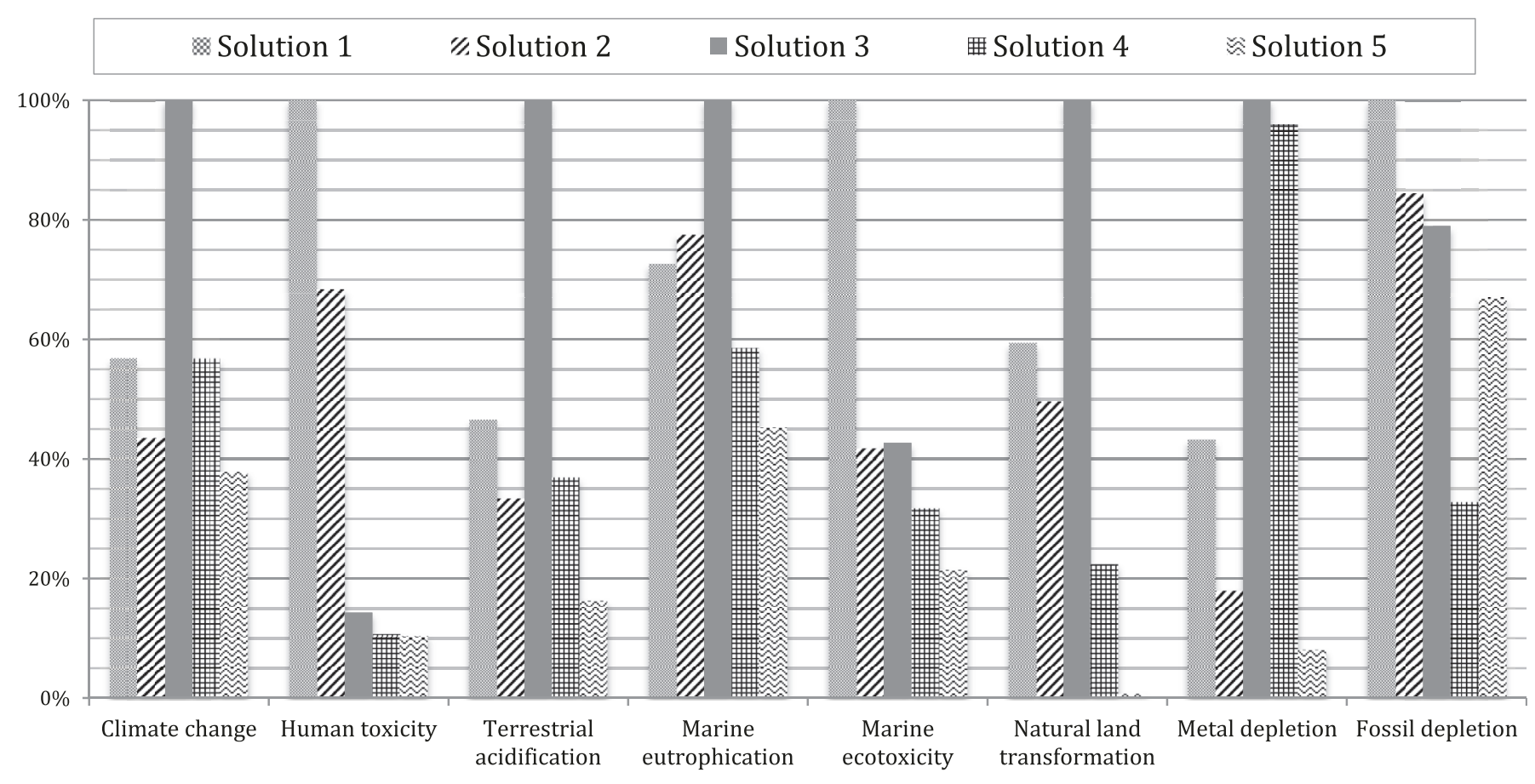

Fig. 7. Characterisation of 5 plywoods, ReCiPe Midpoint $(\mathrm{H})$ method. 
Table 5

Characterisation of 5 plywoods, ReCiPe Midpoint (H) method.

\begin{tabular}{|c|c|c|c|c|c|c|}
\hline Impact category & Unit & Solution 1 & Solution 2 & Solution 3 & Solution 4 & Solution 5 \\
\hline Climate change & $\mathrm{kg} \mathrm{CO} \mathrm{Cl}_{2}$ eq & $2.378 \mathrm{E}+01$ & $1.353 \mathrm{E}+01$ & $1.035 \mathrm{E}+01$ & $1.353 \mathrm{E}+01$ & $9.002 \mathrm{E}+00$ \\
\hline Human toxicity & kg 1,4-DB eq & $1.623 \mathrm{E}+00$ & $1.234 \mathrm{E}+00$ & $7.734 \mathrm{E}+00$ & $1.132 \mathrm{E}+01$ & $1.187 \mathrm{E}+00$ \\
\hline Terrestrial acidification & $\mathrm{kg} \mathrm{SO}_{2}$ eq & $1.678 \mathrm{E}-01$ & $6.205 \mathrm{E}-02$ & $5.618 \mathrm{E}-02$ & $7.826 \mathrm{E}-02$ & $2.751 \mathrm{E}-02$ \\
\hline Marine eutrophication & $\mathrm{kg} \mathrm{N} \mathrm{eq}$ & $7.027 \mathrm{E}-03$ & $4.118 \mathrm{E}-03$ & $5.449 \mathrm{E}-03$ & $5.102 \mathrm{E}-03$ & $3.185 \mathrm{E}-03$ \\
\hline Marine ecotoxicity & kg 1,4-DB eq & $4.859 \mathrm{E}-02$ & $3.622 \mathrm{E}-02$ & $4.756 \mathrm{E}-02$ & $1.138 \mathrm{E}-01$ & $2.451 \mathrm{E}-02$ \\
\hline Natural land transformation & $\mathrm{m}^{2}$ & $2.836 \mathrm{E}-02$ & $6.388 \mathrm{E}-03$ & $1.407 \mathrm{E}-02$ & $1.685 \mathrm{E}-02$ & $2.190 \mathrm{E}-04$ \\
\hline Metal depletion & $\mathrm{kg}$ Fe eq & $2.026 \mathrm{E}+00$ & $1.943 \mathrm{E}+00$ & $3.649 \mathrm{E}-01$ & $8.763 \mathrm{E}-01$ & $1.641 \mathrm{E}-01$ \\
\hline Fossil depletion & $\mathrm{kg}$ oil eq & $4.254 \mathrm{E}+00$ & $1.764 \mathrm{E}+00$ & $4.543 \mathrm{E}+00$ & $5.385 \mathrm{E}+00$ & $3.607 \mathrm{E}+00$ \\
\hline
\end{tabular}

to show the environmental interest of the vacuum moulding process with green maritime pine.

The study of the characterisation of solution 5 has allowed us to determine the influence of each procedure implemented in the manufacturing of plywood glued in a vacuum. We have noticed the dominating influence (between $20 \%$ and $50 \%$ impact according to the indicators) of the PU glue in the impact of solution 5. The consumables necessary for the vacuum gluing are responsible for $20-40 \%$ of the environmental impacts.

This analysis has allowed us to determine the actions to be carried out as a priority in order to reduce this environmental impact. To increment the ecodesign approach, polyurethane adhesive seems to be the priority choice for optimising the gluing of green wood. Some of the paths that could be investigated are for example the weight of glue and the percentage of bio-sourced elements in the formula of the adhesive.

\subsubsection{Normalisation results for the comparison of 5 solutions}

Fig. 8 shows the normalised results of the comparison of 5 solutions of plywood with the ReCiPe normalised method for Europe. On Table 6, the values are multiplied by 100 and shown using logarithmic scale, and give values without any transformation.

Three indicators stand out in the normalisation of Table 6: Human toxicity, Marine ecotoxicity and natural land transformation. For those three indicators the 5th solution helps us to reduce the impacts significantly. Results for the natural land transformation indicator need to be read carefully because a huge uncertainty was found. On the other hand, some of the results for fossil depletion and marine eutrophication are low on normalised representation.

\subsection{Evolution of solution 5}

The study of the network of solution 5 has allowed us to understand better which components are potentially the most impacting on the environment. For example, for the fossil resource depletion indicator, the contribution of polyurethane is close to $70 \%$. These are the components of the polyurethane and not the transformations or the transport that bring about this strong impact. On this same indicator of fossil resource depletion, the consumables contribute at around 25\% with first the absorbent fabric (polyester, $8 \%$ ) then the peel ply (polyamide, $4 \%$ ).

If we consider that the human toxicity indicator, the polyurethane and the consumables are still responsible for the greater part of the impact. These are the steps in the transformations of these products and particularly the fossil fuels that are the most harmful to human health.

Finally, concerning the transformation of the natural land, we still find polyurethanes and consumables in the list of the most destructive elements for the natural land. And as in the case for human toxicity, the transformation of composites into finished or semi-finished products brings about the greatest impact on this indicator. The hierarchy of networks of the other indicators remains similar to that shown by means of these 3 indicators.

Even if vacuum gluing is still only in an experimental phase, we have already been able to demonstrate the environmental gains that can be envisaged with an optimisation of polyurethane and other consumables used. Vacuum glued plywoods put to use have not as yet been optimised, the drying time and the amounts of glue used have been overestimated. These recommendations were to do with possible improvements with a view to making progress in

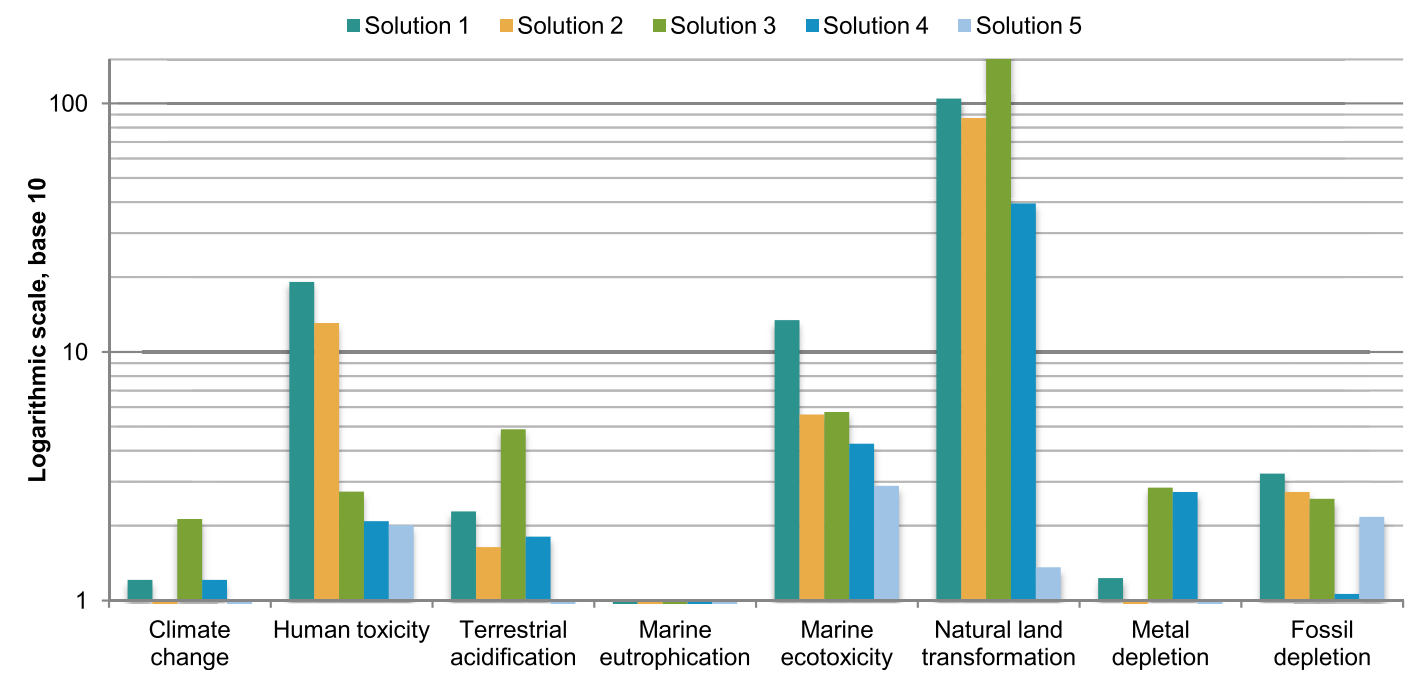

Fig. 8. Normalisation of 5 plywoods - values are multiplied by 1000 , ReCiPe Midpoint $(\mathrm{H})$ method. 
Table 6

Values without multiplication for the normalisation of 5 plywoods, ReCiPe Midpoint $(\mathrm{H})$ method.

\begin{tabular}{|c|c|c|c|c|c|}
\hline Impact category & Solution 1 & Solution 2 & Solution 3 & Solution 4 & Solution 5 \\
\hline Climate change & $2.12 \mathrm{E}-03$ & $1.21 \mathrm{E}-03$ & $9.23 \mathrm{E}-04$ & $1.21 \mathrm{E}-03$ & $8.03 E-04$ \\
\hline Human toxicity & $2.74 \mathrm{E}-03$ & $2.08 \mathrm{E}-03$ & $1.31 \mathrm{E}-02$ & $1.91 \mathrm{E}-02$ & $2.00 \mathrm{E}-03$ \\
\hline Terrestrial acidification & $4.88 \mathrm{E}-03$ & $1.80 \mathrm{E}-03$ & $1.63 \mathrm{E}-03$ & $2.28 \mathrm{E}-03$ & $8.00 \mathrm{E}-04$ \\
\hline Marine eutrophication & $6.95 \mathrm{E}-04$ & $4.07 \mathrm{E}-04$ & $5.39 \mathrm{E}-04$ & $5.04 \mathrm{E}-04$ & $3.15 \mathrm{E}-04$ \\
\hline Marine ecotoxicity & $5.72 \mathrm{E}-03$ & $4.26 \mathrm{E}-03$ & $5.60 \mathrm{E}-03$ & $1.34 \mathrm{E}-02$ & $2.88 \mathrm{E}-03$ \\
\hline Natural land transformation & $1.76 \mathrm{E}-01$ & $3.96 \mathrm{E}-02$ & $8.72 \mathrm{E}-02$ & $1.04 \mathrm{E}-01$ & $1.36 \mathrm{E}-03$ \\
\hline Metal depletion & $2.84 \mathrm{E}-03$ & $2.72 \mathrm{E}-03$ & $5.12 \mathrm{E}-04$ & $1.23 \mathrm{E}-03$ & $2.30 \mathrm{E}-04$ \\
\hline Fossil depletion & $2.56 \mathrm{E}-03$ & $1.06 \mathrm{E}-03$ & $2.73 \mathrm{E}-03$ & $3.24 \mathrm{E}-03$ & $2.17 \mathrm{E}-03$ \\
\hline
\end{tabular}

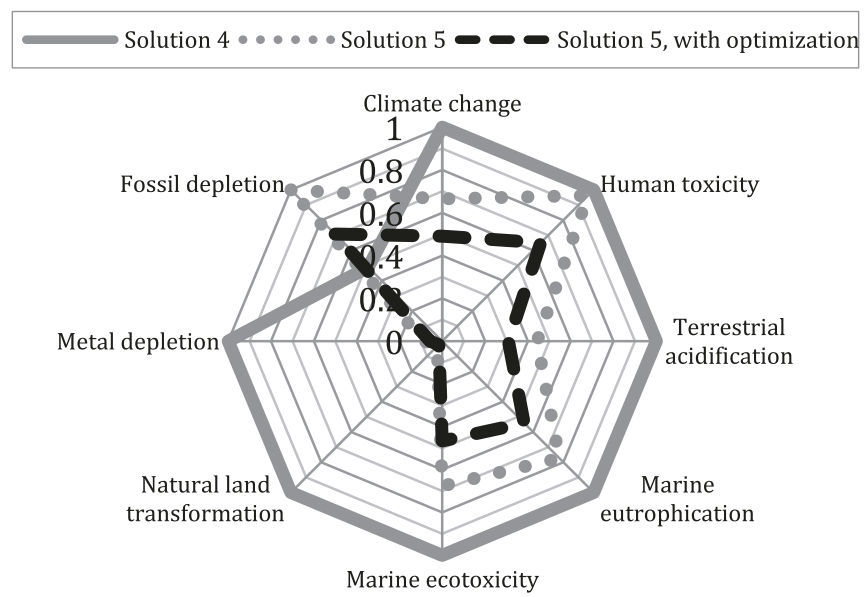

Fig. 9. Characterisation of solution 5 before and after a second optimisation in relation to solution 4, ReCiPe Midpoint $(\mathrm{H})$ method. research and do not yet correspond to the industrialisation of the process.

The first optimisation aims at reducing the amount of adhesive. We have modelled the weight decreasing from $300 \mathrm{~g} / \mathrm{m}^{2}$ to $200 \mathrm{~g} /$ $\mathrm{m}^{2}$ which corresponds to a loss of weight from $1.2 \mathrm{~kg}$ to $800 \mathrm{~g}$ of polyurethane for the plywood measured. The second optimisation limits the vacuum drying time to $1 \mathrm{~h} 30$ instead of $2 \mathrm{~h}$. Finally, the last optimisation concerns the reuse of consumables, increased from 4 times to 5 .

In Fig 9, the vacuum process with no particular optimisation (solution 5) and the same with optimisations (solution 5, with optimisation)were compared (Table 7).

The foreseeable gains are close to $30 \%$ for all of the indicators. These improvements help to accentuate further the gap with the solution where maritime plywood is glued under pressure with phenolic glue. Among other things, the optimisation allows the minimisation of the impact on the operators (human toxicity) and it also reduces the stress on fossil resources and comes close to solution 4 for this indicator.

The results prove that with realistic, minor adjustments the environmental gains made with the green wood gluing can be improved by almost $30 \%$.

Table 7

Characterisation of solution 5 before and after a second optimisation in relation to solution 4, ReCiPe Midpoint (H) method.

\begin{tabular}{|c|c|c|c|c|}
\hline Impact category & Unit & Solution 4 & Solution 5 & Solution 5 optimised \\
\hline Climate change & $\mathrm{kg} \mathrm{CO} \mathrm{CO}_{2}$ & $1.353 \mathrm{E}+01$ & $9.002 \mathrm{E}+00$ & $6.642 \mathrm{E}+00$ \\
\hline Human toxicity & $\mathrm{kg} 1,4-\mathrm{DB}$ eq & $1.132 \mathrm{E}+01$ & $1.187 \mathrm{E}+00$ & $8.027 \mathrm{E}-01$ \\
\hline Terrestrial acidification & $\mathrm{kg} \mathrm{SO}_{2}$ eq & $7.826 \mathrm{E}-02$ & $2.751 \mathrm{E}-02$ & $1.920 \mathrm{E}-02$ \\
\hline Marine eutrophication & $\mathrm{kg} \mathrm{N} \mathrm{eq}$ & $5.102 \mathrm{E}-03$ & $3.185 \mathrm{E}-03$ & $2.230 \mathrm{E}-03$ \\
\hline Marine ecotoxicity & kg 1,4-DB eq & $1.138 \mathrm{E}-01$ & $2.451 \mathrm{E}-02$ & $1.688 \mathrm{E}-02$ \\
\hline Natural land transformation & $\mathrm{m}^{2}$ & $1.685 \mathrm{E}-02$ & $2.190 \mathrm{E}-04$ & $1.455 \mathrm{E}-04$ \\
\hline Metal depletion & $\mathrm{kg}$ Fe eq & $8.763 \mathrm{E}-01$ & $1.641 \mathrm{E}-01$ & $1.106 \mathrm{E}-01$ \\
\hline Fossil depletion & $\mathrm{kg}$ oil eq & $5.385 \mathrm{E}+00$ & $3.607 \mathrm{E}+00$ & $2.555 \mathrm{E}+00$ \\
\hline
\end{tabular}

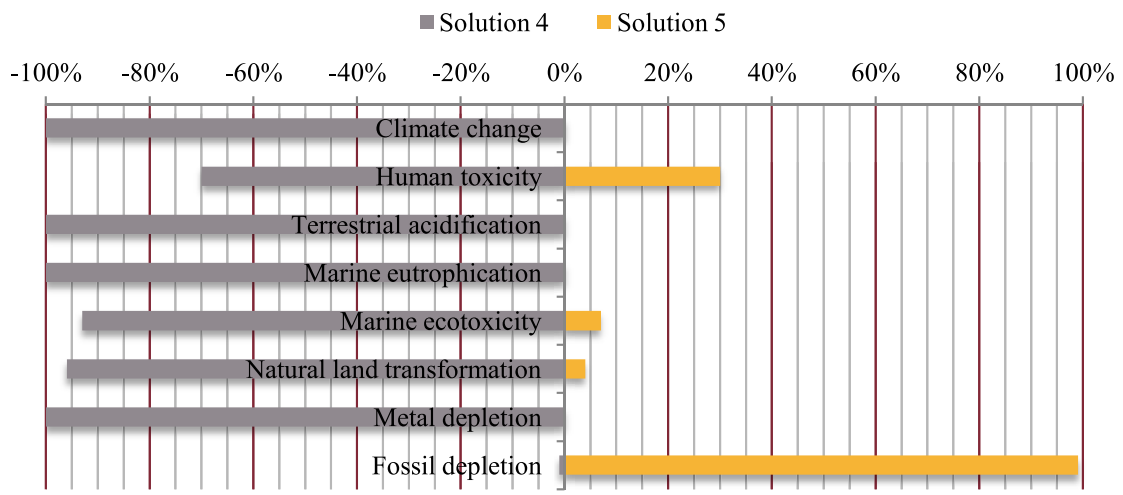

Fig. 10. Analysis of uncertainties: maritime pine plywood, phenolic glue and vacuum gluing. ReCiPe Midpoint hierarchist method (H). 


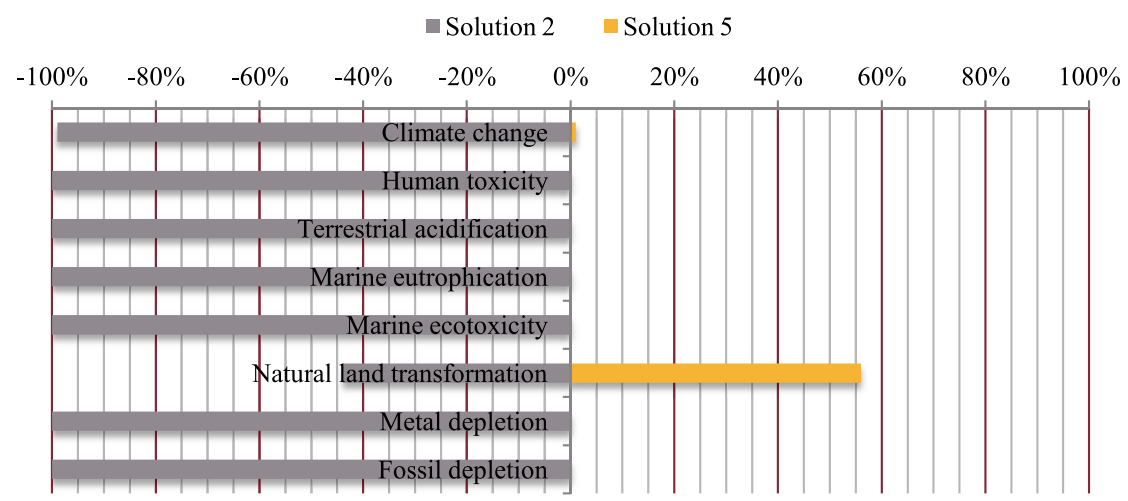

Fig. 11. Analysis of uncertainties: maritime pine plywood, phenolic glue and vacuum gluing. ReCiPe Midpoint hierarchist method (H).

Table 8

Characterisation of 6 plywoods, USEtox method.

\begin{tabular}{|c|c|c|c|c|c|c|c|}
\hline Impact category & Unit & Solution 1 & Solution 2 & Solution 3 & Solution 4 & Solution 5 & Solution 5 optimised \\
\hline Human toxicity, cancer & CTUh & $8.567 \mathrm{E}-07$ & $7.317 \mathrm{E}-07$ & $1.083 \mathrm{E}-06$ & $1.051 \mathrm{E}-06$ & $8.310 \mathrm{E}-07$ & $7.195 \mathrm{E}-07$ \\
\hline Human toxicity, non-cancer & CTUh & $6.081 \mathrm{E}-06$ & $5.334 \mathrm{E}-06$ & $1.535 \mathrm{E}-06$ & $1.420 \mathrm{E}-06$ & $6.163 \mathrm{E}-07$ & $4.757 \mathrm{E}-07$ \\
\hline Ecotoxicity & CTUe & $1.844 \mathrm{E}+01$ & $2.361 \mathrm{E}+01$ & $1.358 \mathrm{E}+01$ & $1.239 \mathrm{E}+01$ & $1.493 \mathrm{E}+01$ & $1.105 \mathrm{E}+01$ \\
\hline
\end{tabular}

\subsection{Uncertainty analysis}

\subsubsection{Uncertainty about the modelling}

We carried out an uncertainty analysis on all of our modellings and in this part we only present the comparisons between the closest results which are solutions 2 and 4 first and then solutions 4 and 5 afterwards.

Fig. 10 shows the uncertainties between the solutions obtained with a Monte Carlo analysis.

The results show that for most of the indicators the analyses are robust and can be used and trusted when it comes to interpreting the results. In fact, only one uncertainty is above $5 \%$ and this is human toxicity. This is why we have chosen to use the USEtox method as well in order to complete our subsequent observations.

Our second comparison concerns the two solutions that use polyurethane glue (solutions 2 and 5) (Fig. 11).

On this second uncertainty analysis the indicator referring to natural land transformation appears to be unusable. However, this indicator has never been subject to comments and it could be removed.

\subsubsection{Uncertainty of the characterisation method}

As explained in Section 2.4.1, we used the USEtox method of characterisation to put our results on the indicators of human toxicity and ecotoxicity into perspective. It also helped us to determine whether the characterisation method is strong enough to bear our results. These results are shown on Fig. 10 (Table 8).

For this comparison we integrated the optimised solution 5, whose characterisations using the ReCiPe method are shown in Fig. 12.

The results shown some slight modifications obtained from the ReCiPe method. Thus the difference between the vacuum plywoods (solutions 5 and 5 optimised) when compared to the solutions present in the Ecoinvent database is less marked on the human toxicity/carcinogen indicator than on the human toxicity indicator. This gap is also weaker for the ecotoxicity indicator. Nevertheless, the hierarchy for all of the indicators is unchanged in relation to the results given in Fig. 5 (ReCiPe method).

\section{Discussion; perspectives and ways of improvement}

During the data collection for the Life Cycle Inventory and during the Life Cycle Impact Assessment study we identified three priorities to optimise the manufacturing of plywood with green veneers and vacuum technology.

These three topics are just as valid for boat building and particularly for the construction of wooden boats at the Dubourdieu boatyards, as well as in a wider perspective. These topics are as follows: a reflection on the raw material used, an improvement of the stages in the plywood construction and an optimisation of the manufacturing process in order to anticipate the industrialisation of the procedure.

The so-called $3 \mathrm{R}$ approach (reduce, re-use, recycle) guided some of the recommendations suggested. The technology for vacuum gluing green wood allows a better adaptability of something that used to be a standard product and that now offers new prospects for its use. Nevertheless, this new technology must reduce its reliance on non-renewable fossil and mineral resources. Instead we

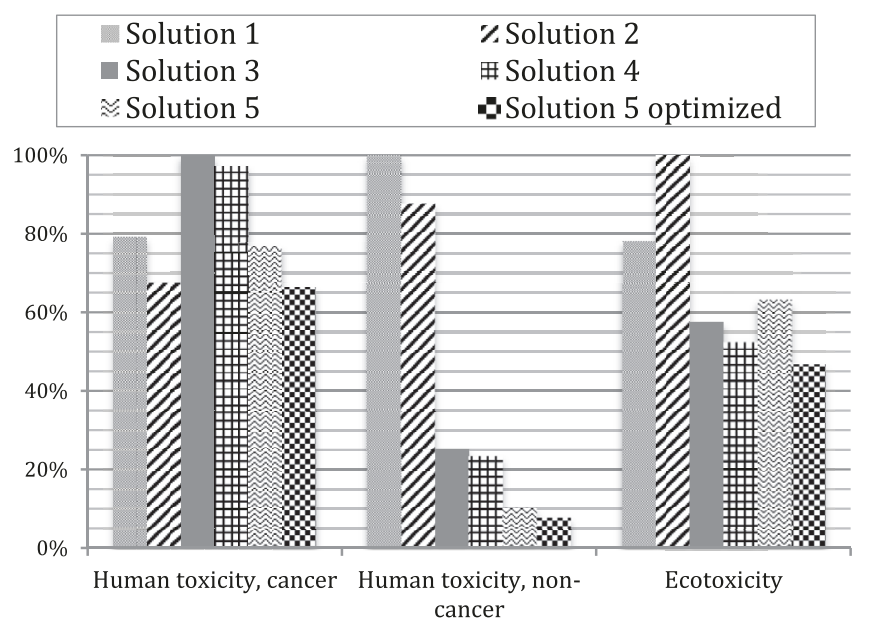

Fig. 12. Characterisation of 6 plywoods, USEtox method. 
should give preference to re-using consumables. This also requires planning for the sorting of different materials at the end of their life cycle. Competitive recycling systems need to be set up.

\subsection{Thematic areas for the raw materials used}

\subsubsection{Innovative wood materials}

Wood quality needs to be improved in order to get a more homogeneous result and to reduce losses before the assembling of veneers. In this study, these losses are around $40 \%$ and they consist of clean, unglued wood, reused for heating (wood as energy source).

We observed that polyurethane is more eco-friendly than phenolic glue. Moreover, besides its interesting environmental performances, it allows a reduction in energy requirements. It is not necessary to heat the panel during the end pressure. Nevertheless, its role in the global impact of the vacuum gluing solution is particularly high. The reduction in the quantity of glue used offers the chance of effectively reducing the impact of plywood, while retaining its mechanical properties. The other path of improvement concerning the glue, aims at finding bio-based material to avoid putting a strain on fossil resources.

However, the consumables are also responsible for a large percentage of the total environmental impact. The consumables (Airtight canvas, Drain canvas, Removal wax, for example in our case) are mainly in plastic and constitute a significant proportion of the waste. Reusing them more than 5 times seems difficult when considering their quality and their endurance after $4-5$ uses. The way forward to be explored relies above all on alternative solutions which will allow plastic materials or even the consumables themselves to be replaced.

\subsubsection{Prefer local resources}

We have seen that vacuum moulding allows the manufacture of products that are well adjusted to the final dimensions and with a very good quality finish. In this context, manufacturers have more flexibility in what they make and in their products. The technology described in this article is still in the research stage and work needs to be carried out to adapt the technique to woods other than coniferous or deciduous species.

At the Dubourdieu 1800 boatyard, and in its search for ecodesign, the use of maritime pine is extremely popular since the construction site is located on the bay of Arcachon. This geographical situation means that for the boat building there, the logistics and the demand for raw materials are reduced and therefore so are the environmental and social impacts. In fact, the stocks of wood in the Landes forest mean there can be a local answer when it comes to supplying the boatyard with its primary raw material.

\subsection{Optimisation of the stages for implementation}

\subsubsection{Reduce the environmental impact of the transformations}

The exploitation of wood, the raw material, is a good thing for the environment but the transformations necessary and the logistics involved have the greatest impact on the environmental in the solutions under study. Energy sources with lower carbon footprints must be studied in order to guarantee at least a carbon neutral solution.

\subsubsection{Optimise the logistic of wood plies}

Vacuum gluing is penalised by the losses in wood that occur when the process is carried out. In our study, losses are around $40 \%$, so we need to find solutions which will allow gluing to be optimised in order to reduce these losses; for example, reusing the offcuts from internal plies or else finding parallel activities to valorise these offcuts.

\subsubsection{Improve the management of manufacturing waste}

For the moment, the inconvenience of the solution of gluing green wood is that it produces large quantities of waste (wood and plastic). We therefore need to find and put in place the best solutions for reducing, reusing and recycling all types of waste. The priority during the gluing operation must be to reduce the amount of waste produced as well as to set up a sorting programme for downstream recycling and material recovery.

\subsubsection{The health of operators and users}

Limiting the emissions of hazardous substances and the exposure to them must be addressed to safeguard the health of operators and users. This begins by reducing or even eliminating toxic components. Changing from phenolic resin to polyurethane glue is a step in the right direction and there have already been good results for operators' health with the elimination of formaldehyde emissions.

\subsection{Preparing the industrialisation of the procedure}

The guiding strategy behind the implementation of vacuum gluing of green wood was to propose this to industrial manufacturers of innovative wood products. The next stage in the research is to find techniques for industrialising the solution and thereby open up commercial prospects for this innovative solution.

This industrialisation has to answer two criteria: maintain the environmental gains made by the proof of vacuum gluing and offer manufacturers a machine able to produce moulded plywood at the best price possible. In the first case, the technical installations would have to function autonomously at a rate close to that of conventional equipment.

The technological solution will be both simple to minimise the costs and flexible in order to answer particularities in the shapes of plywood to be made with vacuum.

\section{Conclusion}

The LCA carried out allowed the creation of the first reference in the environmental evaluation of wood-based boat building plywood. Hence, the results obtained made possible extrapolation for other green wood gluing products.

Different types of glue and woods have been compared. It appears that the Polyurethane adhesive and a local wood were significantly attractive compared to the other solutions.

The global LCA model shows that there is a significant interest in the technology of gluing green wood with a vacuum process compared to the conventional approach. Gluing green wood applied to plywood vacuum moulding could reduce considerably the number of steps in its manufacture.

The LCA has allowed us to highlight the pollution transfers, however, is based on measurements for a technology at a given moment and for a given solution. For example, the data's from the fifth solution (vacuum moulding) have been collected in laboratory conditions. The aim is to succeed in further tools integration in the upstream phase of the design, as a driver for eco-innovation. In fact the LCA has allowed the identification of the environmental hotspots in the procedure and given ideas for its improvement during its implementation in industrial production.

As consequence a follow-up will be done on methods of industrial up-scaling in order to guarantee the sustainability of the environmental gains. 


\section{Acknowledgements}

The authors thank Cluster ABOVE and Dubourdieu 1800 boat builders (M Emmanuel Martin) who constructed Greencanot and who gave us a great deal of data for our LCA.

We would also like to thank Pr Tatiana Reyes (Université de technologie de Troyes), Dre Anne Lavalette (Université Bordeaux 1).

We would like to thank the Region of Aquitaine for their financial support that helped to make the study feasible.

\section{References}

Bare, J.C., Hofstetter, P., Pennington, D.W., Haes, H.A.U., 2000. Midpoints versus endpoints: the sacrifices and benefits. Int. J. Life Cycle Assess. 5, 319-326. http://dx.doi.org/10.1007/BF02978665.

Bertram, C., Rehdanz, K., 2013. On the environmental effectiveness of the EU Marine Strategy Framework Directive. Mar. Policy 38, 25-40. http://dx.doi.org/10.1016/ j.marpol.2012.05.016.

Bureau Veritas, 2012. Rule Admissible - Stress and Safety Coefficients (Pt B, Ch $6-7)$.

Clouet, B., Pommier, R., Danis, M., 2013. New composite timbers: full-field analysis of adhesive behavior. J. Strain Anal. Eng. Des. 49, 155-160. http://dx.doi.org/ $10.1177 / 0309324713486894$.

Curran, M.A., 2012. Life Cycle Assessment Handbook: a Guide for Environmentally Sustainable Products. John Wiley \& Sons.

Dunky, M., Källander, B., Properzi, M., Richter, K., Van Leemput, M., 2008. Part 2: green gluing. In: Core Document of the COST Action E34 Bonding of Timber, pp. 93-154.

Ecoinvent, 2014. http://www.ecoinvent.ch/.

EN 13986, 2004. Wood-based Panels for Use in Construction - Characteristics, Evaluation of Conformity and Marking. Afnor.

EN 313, 1999. Plywood - Classification and Terminology. Afnor.

EN 314, 2004. Plywood - Bonding Quality. Afnor.

Enquist, B., Sterley, M., Serrano, E., Oscarsson, J., 2014. Green-Glued Products for Structural Applications. Mater. Joints Timber Struct. Recent Dev. Technol.. In: RILEM Bookseries, pp. 45-55.

Eshun, J.F., Potting, J., Leemans, R., 2012. Wood waste minimization in the timber sector of Ghana: a systems approach to reduce environmental impact. J. Clean. Prod. 26, 67-78. http://dx.doi.org/10.1016/j.jclepro.2011.12.025.

European Commission - Joint Research Centre - Institute for Environment and Sustainability, 2010. ILCD Handbook: General Guide on LCA - Detailed Guidance. In: first ed. The International Reference Life Cycle Data System (ILCD) Handbook. Publications Office of the European Union, Ispra, Italy, p. 417. http:// dx.doi.org/10.2788/38479.

FCBA, 2012a. FDES: Bardage en panneaux de contreplaqué français en okoumé résine phénolique (résine phénol-formol).

FCBA, 2012b. FDES;: Plancher en panneaux de contreplaqué français en pin maritime résine phénolique (résine phénol-formol).

FIBA, Bureau Veritas, 2011. Analyse du Cycle de Vie Bois de structure (ossature/ charpente) en pin maritime massif.

González, A., Donnelly, A., Jones, M., Chrysoulakis, N., Lopes, M., 2013. A decisionsupport system for sustainable urban metabolism in Europe. Environ. Impact Assess. Rev. 38, 109-119. http://dx.doi.org/10.1016/j.eiar.2012.06.007.

González-García, S., García Lozano, R., Buyo, P., Pascual, R.C., Gabarrell, X., Rieradevall i Pons, J., Moreira, M.T., Feijoo, G., 2012a. Eco-innovation of a wooden based modular social playground: application of LCA and DfE methodologies. J. Clean. Prod. 27, 21-31. http://dx.doi.org/10.1016/j.jclepro.2011.12.028.

González-García, S., García Lozano, R., Moreira, M.T., Gabarrell, X., Rieradevall i Pons, J., Feijoo, G., Murphy, R.J., 2012b. Eco-innovation of a wooden childhood furniture set: an example of environmental solutions in the wood sector. Sci. Total Environ. 426, 318-326. http://dx.doi.org/10.1016/j.scitotenv.2012.03.077.

González-García, S., Bonnesoeur, V., Pizzi, A., Feijoo, G., Moreira, M.T., 2013. The influence of forest management systems on the environmental impacts for Douglas-fir production in France. Sci. Total Environ. 461-462, 681-692. http:// dx.doi.org/10.1016/j.scitotenv.2013.05.069.
Heebink, B.G., 1953. Fluid-Pressure Molding of Plywood. Forest Product Laboratory Madison, Wisconsin, USA.

Huijbregts, M., Hauschild, M., Jolliet, O., Margni, M., McKone, T., Rosenbaum, R.K. van de Meent, D., Report, 2010. USEtox User Manual.

ISO 14040,2006 . Life cycle assessment - principles and framework. Environ. Manag. 3, 28. http://dx.doi.org/10.1002/jtr.

ISO 14044, 2006. Life Cycle Assessment - Requirements and Guidelines. Switzerland, Geneva.

Karastergiou, S., Mantanis, G.I., Skoularakos, K., 2008. Green gluing of oak wood (Quercus conferta L.) with a one-component polyurethane adhesive. Wood Mater. Sci. Eng. 3, 79-82. http://dx.doi.org/10.1080/17480270802605537.

Kutnar, A., Hill, C., 2014. Assessment of carbon footprinting in the wood industry. In: Muthu, Subramanian Senthilkannan (Ed.), Assessment of Carbon Footprint in Different Industrial Sectors, vol. 2. Springer, Singapore, pp. 135-172 (EcoProduction).

Lavalette, A., Pommier, R., Danis, M., Castéra, P., 2012. Tension-shear (TS) failure criterion for wood composite designed for shipbuilding applications. In: World Conf. Timber Eng. Sessin 11, p. 8.

Lavalette, A., Coiste, A., Pommier, R., Danis, M., Delisee, C., Legrand, G., 2016 Experimental design to determine the manufacturing parameters of a greenglued plywood panel. Eur. J. Wood Wood Prod. http://dx.doi.org/10.1007/ s00107-016-1015-4.

Lippke, B., Wilson, J.B., 2010. Introduction to special issue: extending the findings on the environmental performance of wood building materials. Wood Fiber Sci. 42. ISSN 0735-6161.

Ministry of Housing Spatial Planning and the Environment, 2009. ReCiPe 2008, first ed. Report I: Characterisation.

Mirabella, N., Castellani, V., Sala, S., 2014. LCA for assessing environmental benefit of eco-design strategies and forest wood short supply chain: a furniture case study. Int. J. Life Cycle Assess. 19, 1536-1550. http://dx.doi.org/10.1007/s11367014-0757-7.

NCASI, 1999. Volatile Organic Compound Emissions from Wood Products Manufacturing Facilities, Part V - Oriented Strandboard. National Council for Air and Stream Improvement, Inc. Sustainability Assessment of OSB and Softwood Plywood Manufacturing in North America, Research Triangle Park.

Ng, R., Shi, C.W.P., Tan, H.X., Song, B., 2014. Avoided impact quantification from recycling of wood waste in Singapore: an assessment of pallet made from technical wood versus virgin softwood. J. Clean. Prod. 65, 447-457. http:// dx.doi.org/10.1016/j.jclepro.2013.07.053.

Ngo, D., Pfeiffer, E., 2003. Bent Ply: the Art of Plywood Furniture. Princeton Architectural Press.

Pizzi, Antonio, Mittal, K., 2011. Wood Adhesives. CRC Press.

Pommier, R., Elbez, G., 2006. Finger-jointing green softwood: evaluation of the interaction between polyurethane adhesive and wood. Wood Mater. Sci. Eng. 1, 127-137. http://dx.doi.org/10.1080/17480270701217269.

Pommier, R., Grimaud, G., Prinçaud, M., Perry, N., Sonnemann, G., 2016. Comparative environmental life cycle assessment of materials in wooden boat ecodesign. Int. J. Life Cycle Assess. 21, 265-275. http://dx.doi.org/10.1007/s11367-0151009-1.

Ren, D., Frazier, C.E., 2012. Wood/adhesive interactions and the phase morphology of moisture-cure polyurethane wood adhesives. Int. J. Adhes. Adhes. 34, 55-61. http://dx.doi.org/10.1016/j.ijadhadh.2011.12.009.

Réseau EcoNav, 2012. Analyse des impacts environnementaux de bateaux de plaisance équipés. Douarnenez.

Rosenbaum, R.K., Bachmann, T.M., Gold, L.S., Huijbregts, M.A.J., Jolliet, O., Juraske, R., Koehler, A., Larsen, H.F., MacLeod, M., Margni, M., McKone, T.E., Payet, J., Schuhmacher, M., Meent, D., Hauschild, M.Z., 2008. USEtox-the UNEP-SETAC toxicity model: recommended characterisation factors for human toxicity and freshwater ecotoxicity in life cycle impact assessment. Int. J. Life Cycle Assess. 13, 532-546. http://dx.doi.org/10.1007/s11367-008-0038-4.

Serrano, E., Oscarsson, J., Enquist, B., Sterley, M., Petersson, H., Källsner, B., 2010 Green-Glued Laminated Beams: High Performance and Added Value. WCTE2010.

Tukker, D.A., 2002. Handbook on Life Cycle Assessment: Operational Guide to the ISO Standards. Springer, $692 \mathrm{pp}$.

Werner, F., 2004. Review in Conformity with ISO 14044FF. Module D. Softwood Plywood Manufacturing. Wilson and Sakimoto. 10.

Wilson, J.B., 2010. Life-cycle inventory of particleboard in terms of resources, emissions, energy and carbon. Wood Fiber Sci. 42, 90-106. 